\title{
Novel Syntheses of Some 1, 2, 4-Triazoles as Potent Bacteriocidal Agents
}

\author{
RAM JANAM SINGH* and DHARMENDRA KUMAR SINGH ${ }^{\dagger}$ \\ *Quality Control Laboratory, Indian Oil Corporation Limited, \\ Panipat Refinery Panipat, Haryana-132140, India. \\ ${ }^{\dagger}$ Department of Chemistry, Synthetic Research Laboratory, \\ Faculty of Science, Tilak Dhari Post Graduate College, \\ Veer Bahadur Singh Purvanchal University, Jaunpur-222002 (U.P), India. \\ singhram@iocl.co.in
}

Received 20 March 2009; Revised 15 June 2009; Accepted 10 August 2009

\begin{abstract}
A facile syntheses of 4-aryl-5-(isomeric pyridoyl)-3H-1, 2, 4triazoles as potent bacteriocidal agents are described. The newly synthesized compounds were characterized by spectral and elemental analyses. Some compounds were screened for their antibacterial activity against $S$. aureus, $E$. coli, B. subtilis and P.aeruginosa. All compounds carrying 1, 2, 4- triazole moiety showed significant biological activity.
\end{abstract}

Keywords: 1, 2, 4-Triazoles, 4-Methylphenyl isothiocyanate, Cyclization, Antibacterial activity.

\section{Introduction}

The chemistry of heterocyclic compounds continuous to be an explore field in the organic chemistry. The importance of 1,2,4-triazole derivative lies in the field that these have occupied an unique position in heterocyclic chemistry due to their antimicrobial activity ${ }^{1-3}$. 2,4-Dihydro-4-(4-methylphenyl)-5-(isomeric pyridyl)-3 $\mathrm{H}$-1,2,4-triazoles have been obtained by treating 1-(4-methylphenyl)-(isomeric pyridoyl) thiosemicarbazides and $2 \mathrm{M}$ sodium hydroxide solution through the cyclization reaction. In views of these observations and in continuation of our earlier work ${ }^{4-8}$ on the syntheses of some $1,2,4-\& 1,2,3$-triazole derivatives, we now report the syntheses of some more triazoles derived from 1-(4-methylphenyl)-(isomeric pyridoyl) thiosemicarbazides and their antibacterial activities.

\section{Experimental}

Melting and boiling points were determined on a Gallen Kamp apparatus in open capillaries and are uncorrected. IR spectra $\left(\mathrm{KBr}\right.$ in $\left.\mathrm{cm}^{-1}\right)$ were recorded on a Jasco FT-IR 5300 spectrophotometer and PMR spectra (DMSO-d6) on an EM 390 spectrometer using TMS as an internal standard (chemical shift in $\delta \mathrm{ppm}$ ). Purity of the compounds was checked by TLC using silica gel G. All compounds showed satisfactory elemental analyses. 


\section{4-Methylphenyl isothiocyanate (1)}

A mixture of 4-methylphenyl amine $(0.01 \mathrm{~mol})$, carbon disulfide $(0.01 \mathrm{~mol})$ and methanol $(50 \mathrm{~mL})$ was cooled to $15{ }^{\circ} \mathrm{C}$. Ammonia $(0.01 \mathrm{~mol})$ was added drop wise to the reaction mixture with continuous stirring. The mixture was allowed to stand overnight. Water was added to the mixture $(350 \mathrm{~mL})$. An aqueous solution of lead nitrate $(0.01 \mathrm{~mol})$ was slowly added to the solution. The mixture was then steam distilled to yield 4-methylphenyl isothiocyanate (1). The IR $(\mathrm{KBr})$ of the isolated 4-methylphenyl isothiocyanate indicates a prominent characteristic band at $2071 \mathrm{~cm}^{-1}$ attributed to an $\mathrm{N}=\mathrm{C}=\mathrm{S}$ group (yield $70 \%$ ).

\section{1-(4-Methylphenyl-(isomeric pyridoyl) thiosemicarbazides (2a-c)}

Pyridine carboxylic acid hydrazides (a-c) $(0.01 \mathrm{~mol})$ were reacted with 4-methylphenyl isothiocyanate $(0.01 \mathrm{~mol})$ in the presence of absolute ethanol $(50 \mathrm{~mL})$; was refluxed for 1.5 hours. On cooling the mixture to room temperature, a white solid appeared. The crude solid was filtered, washed with water and recrystallized from appropriate solvent to give compounds (2a-c) yield (70-85\%).

\section{2,4-Dihydro-4-(4-methylphenyl)-5-(isomeric pyridyl) -3H-1,2,4-triazoles (3a-c)}

\section{General procedure}

A mixture of compounds (2a-c) $(0.01 \mathrm{~mol})$ and $2 \mathrm{M}$ sodium hydroxide solution $(30 \mathrm{~mL})$ was refluxed for the period of 40 minutes. The resulting solution was cooled and poured on crushed ice. The solid separated was filtered, washed with water and recrystallized from ethanol-water to give compounds (3a-c) yield (75-85\%).

3a: Yield 85\%, m.p. $235{ }^{\circ} \mathrm{C}$, Anal.Calc. for $\mathrm{C}_{14} \mathrm{H}_{12} \mathrm{~N}_{4} \mathrm{~S}$ : C, 63.02; H, 4.61; N, 11.81\%; Found: C, 63.22; H, 4.41; N, 11.91\%. IR (KBr): $1588(\mathrm{C}=\mathrm{N}), 1510(\mathrm{C}-\mathrm{N}), 730,715$ (monosubstituted benzene) and $690 \mathrm{~cm}^{-1}(\mathrm{C}-\mathrm{S})$; PMR: $\delta 2.35\left(3 \mathrm{H}, \mathrm{s}, \mathrm{CH}_{3}\right) ; 3.32(1 \mathrm{H}, \mathrm{bs}, \mathrm{SH})$; 7.12(2H,m,Aromatic-H); 7.31(2H,m, Aromatic-H); 7.39 (1H,m,Pyridyl-H), 7.78(1H,m, Pyridyl-H), 7.88(1H,m,Pyridyl-H) and 8.42 ppm (1H,m,Pyridyl-H); MS : m/z $265\left(\mathrm{M}^{+}\right)$ other peaks were observed at 263,207,163,107,95,81 and 53 .

3b: Yield 75\%, m.p. $235{ }^{0} \mathrm{C}$, Anal.Calc. for $\mathrm{C}_{14} \mathrm{H}_{12} \mathrm{~N}_{4} \mathrm{~S}$ : C, 63.08; H, 4.58; N, 11.88\%; Found: C, 63.20; H, 4.39; N, 11.86\%. IR (KBr): $1587(\mathrm{C}=\mathrm{N}), 1511(\mathrm{C}-\mathrm{N}), 732,712$ (monosubstituted benzene) and $699 \mathrm{~cm}^{-1}(\mathrm{C}-\mathrm{S})$; PMR: $\delta 2.35\left(3 \mathrm{H}, \mathrm{s}, \mathrm{CH}_{3}\right) ; 3.26(1 \mathrm{H}, \mathrm{bs}, \mathrm{SH})$; 7.21 (2H,d,Aromatic-H); 7.29 (2H,d, Aromatic-H); 7.38 (1H,m,Pyridyl-H), 7.66 (1H,m,Pyridyl-H), 8.45 (1H,dd,Pyridyl-H) and $8.55 \mathrm{ppm}(1 \mathrm{H}, \mathrm{m}$, Pyridyl-H); MS : $m / z, 265$ $\left(\mathrm{M}^{+}\right)$other peaks were observed at 263,207,163,107,95,81 and 53 .

3c: Yield 85\%, m.p. $235^{\circ} \mathrm{C}$, Anal.Calc. for $\mathrm{C}_{14} \mathrm{H}_{12} \mathrm{~N}_{4} \mathrm{~S}: \mathrm{C}, 63.05 ; \mathrm{H}, 4.62 ; \mathrm{N}, 11.83 \%$; Found: C, 63.18; H, 4.37; N, 11.87\%. IR (KBr): $1586(\mathrm{C}=\mathrm{N}), 1515(\mathrm{C}-\mathrm{N}), 735,710$ (monosubstituted benzene) and $688 \mathrm{~cm}^{-1}(\mathrm{C}-\mathrm{S})$; PMR: $\delta 2.28\left(3 \mathrm{H}, \mathrm{s}, \mathrm{CH}_{3}\right) ; 6.40(1 \mathrm{H}, \mathrm{bs}, \mathrm{SH}) ; 7.10(2 \mathrm{H}, \mathrm{d}$, Aromatic-H); 7.31(2H,d,Aromatic-H);7.65(2H,m,Pyridyl-H) and $8.82 \mathrm{ppm}(2 \mathrm{H}, \mathrm{m}$, Pyridyl-H); MS: $m / z 269$ $\left(\mathrm{M}^{+}\right)$other peaks were observed at 266,210,209,162,105,92,79,59 and 51 .

\section{Antibacterial activity}

The antibacterial activity of three compounds was studied by employing filter paper disc method $^{9-12}$. Representative organisms selected for evaluation of antibacterial activity were $S$. aureus, E.coli, B.subtilis and P.aeruginosa. The antibacterial activity of each compound was evaluated at $100 \mu \mathrm{g} \mathrm{mL}^{-1}$ and $10 \mu \mathrm{g} \mathrm{mL}^{-1}$ concentrations. The compounds were tested as a solution or suspension in DMF. An important and useful drug ampicillin was also tested under similar conditions, with view to compare the results. 
Ampicillin is a beta-lactam antibiotic ${ }^{13}$ that has been used extensively to treat bacterial infections since 1961. Ampicillin is designated chemically as $(2 \mathrm{~S}, 5 \mathrm{R}, 6 \mathrm{R})-6-([(2 \mathrm{R})-2-$ amino-2-phenylacetyl] amino)-3, 3-dimethyl-7-oxo-4-thia-1-azabicyclo [3.2.0] heptane-2carboxylicacid. Ampicillin is able to penetrate gram-positive and some gram-negative bacteria $^{14}$. Ampicillin acts as a competitive inhibitor of enzyme transpeptidase.

The results indicate that all three compounds showed good activity. (Table 1) All three compounds showed very good activity against S. aureus, E.coli, B.subtilis and P.aeruginosa. From the above observation it is clear that the 1,2, 4-triazole derivatives are more active and play a prominent role in the biological activity.

Table 1. Evaluation of antibacterial activity of the compounds.

\begin{tabular}{ccccccccc}
\hline Compd. & \multicolumn{7}{c}{ S. aureus } & \multicolumn{2}{c}{ E. coli } & B. subtilis & \multicolumn{2}{c}{ P.aeruginosa } \\
\cline { 2 - 8 } & 100 & 10 & 100 & 10 & 100 & 10 & 100 & 10 \\
& $\mu \mathrm{g} \mathrm{mL}^{-1}$ & $\mu \mathrm{g} \mathrm{mL}$ & $\mu \mathrm{g} \mathrm{mL}^{-1}$ & $\mu \mathrm{g} \mathrm{mL}^{-1}$ & $\mu \mathrm{gL} \mathrm{m}^{-1}$ & $\mu \mathrm{gL} \mathrm{m}^{-1}$ & $\mu \mathrm{g} \mathrm{mL}$ & $\mu \mathrm{gL}^{-1}$ \\
\hline 3a & 15 & 14 & 16 & 14 & 15 & 13 & 16 & 13 \\
3b & 17 & 14 & 14 & 13 & 15 & 13 & 16 & 14 \\
3c & 16 & 15 & 13 & 13 & 17 & 13 & 15 & 13 \\
Standard & & & & & & & & \\
(Ampicillin) & 27 & 21 & 24 & 20 & 24 & 20 & 24 & 20 \\
Control & 00 & 00 & 00 & 00 & 00 & 00 & 00 & 00 \\
\hline
\end{tabular}

\section{Results and Discussion}

In the present work, compound 1-(4-methylphenyl) -(isomeric pyridoyl) thiosemicarbazides (2) required as starting material was obtain in one-pot reaction by condensing 4methylphenyl isothiocyanate (1) with Acid hydrazide. The required 4-methylphenyl isothiocyanate (1) was prepared from the treatment of 4-methyl aniline with carbon disulfide and ammonia in methanol and then reacted with lead nitrate. 1-(4-Methylphenyl)-(isomeric pyridoyl) thiosemicarbazides (2) was converted to the corresponding 2, 4-Dihydro-4-(4methylphenyl)-5-(isomeric pyridyl)-3H-1, 2, 4-triazoles (3) by acid/base catalyzed intramolecular dehydrative cyclization reaction. (Scheme 1)

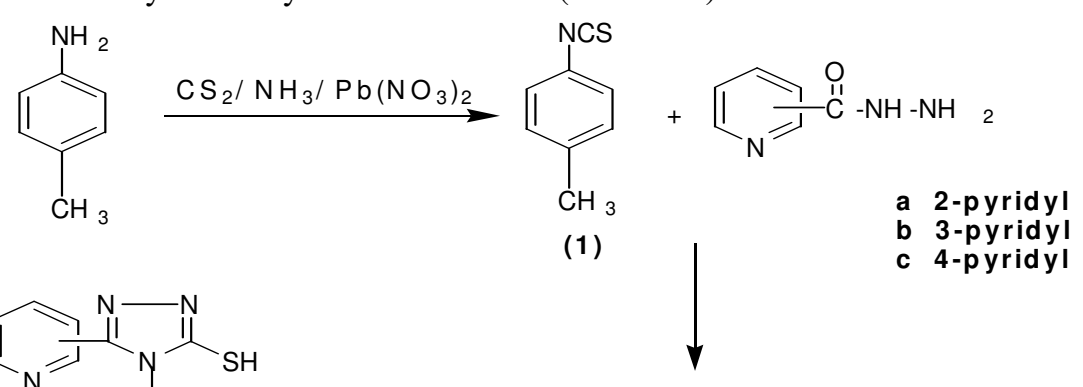<smiles>Cc1ccc(-n2c(S)nnc2-c2ccccn2)cc1</smiles>

(3a-c)<smiles>Cc1ccc(N=C=S)cc1</smiles>

(2a-c)

Scheme 1. 


\section{Conclusion}

In conclusion, a group of 1,2, 4-triazole derivatives were synthesized and characterized. All these compounds containing 1, 2, 4-triazole moiety is more active and plays a prominent role in biological activity. The structure of all the compounds are confirmed by IR, PMR \& MS spectral data and are further supported by correct elemental analysis.

\section{Acknowledgement}

The authors are thankful to Head, RSIC, CDRI, Lucknow for analytical and spectral data. Head of the Department of Microbiology, I.M.S. B.H.U. for biological screening and to the Head of the Chemistry Department of Tilak Dhari Post Graduate College, Jaunpur for providing Laboratory facilities.

\section{References}

1 Zeeh B and Goetz H, J Indian Chem Soc., 1981, 280, 2923-2926.

2 Gamala A and Ahmed M, J Indian Chem Soc., 1997, 74, 624-625.

3 Parmar S S, Choudhary M, Choudhary S K, Kumar S and Sapiro H R, J Parm Sci., 1997, 66, 971-973.

4 Singh D K, Singh R J, Mahadevan K M, Vagdevi H M and Vaidha V P, Indian J Chem., 2003, 42B, 1931-1932.

$5 \quad$ Singh R J and Singh D K, E Journal of Chemistry, 2009, 6(3), 796-800.

6 Singh R J, J Purvanchal Academy of Sciences, 2006, 12 (Ser.B), 21-24.

7 Singh R J and Singh D K, E Journal of Chemistry, 2009, 6(S1), S219-S224.

8 Singh R J and Singh D K, S Afr J Chem., 2009, 62,105-108..

9 Cruickshank R, Duguid J P, Marmoin B P and Swam H A, Eds., The practice of Medical Microbiology,vol.3, $12^{\text {th }}$ Ed., Churchill Living stone, London, 1975, pp.544.

10 Bradshaw L J, Ed., A Text book of Microbiology, 1979, pp.1151-1162.

11 Rich S and Horsfall J G, Phytopathology, 1952, 42, 477-480.

12 Seeley H W and Vandenmark P J, Microbes in action: A Laboratory Mannual of Microbiology, D.B.Taraporevala \& Sons Pvt. Ltd. Bombay, 1975, pp.55-88.

13 Elene J B and Sydney M F, Methods for testing Antimicrobial Effectiveness, Diagnostic Microbiology, Mosiy Company, USA, pp.171-194.

14 Ersan S, Nacak S and Berken R, Farmaco, 1998, 53, 773-776. 


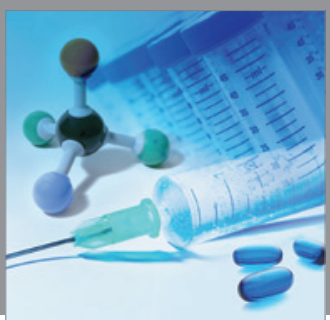

International Journal of

Medicinal Chemistry

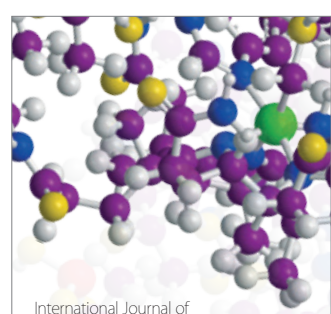

Carbohydrate Chemistry

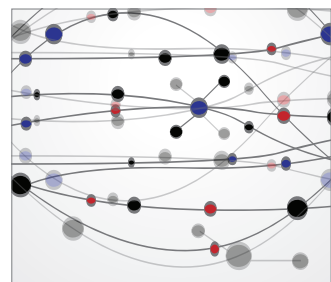

The Scientific World Journal
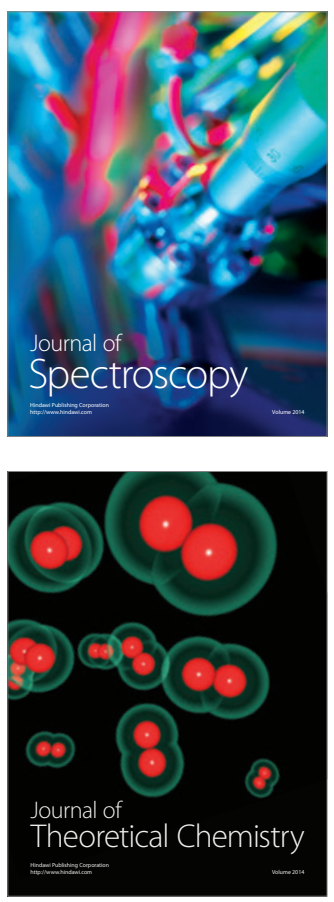
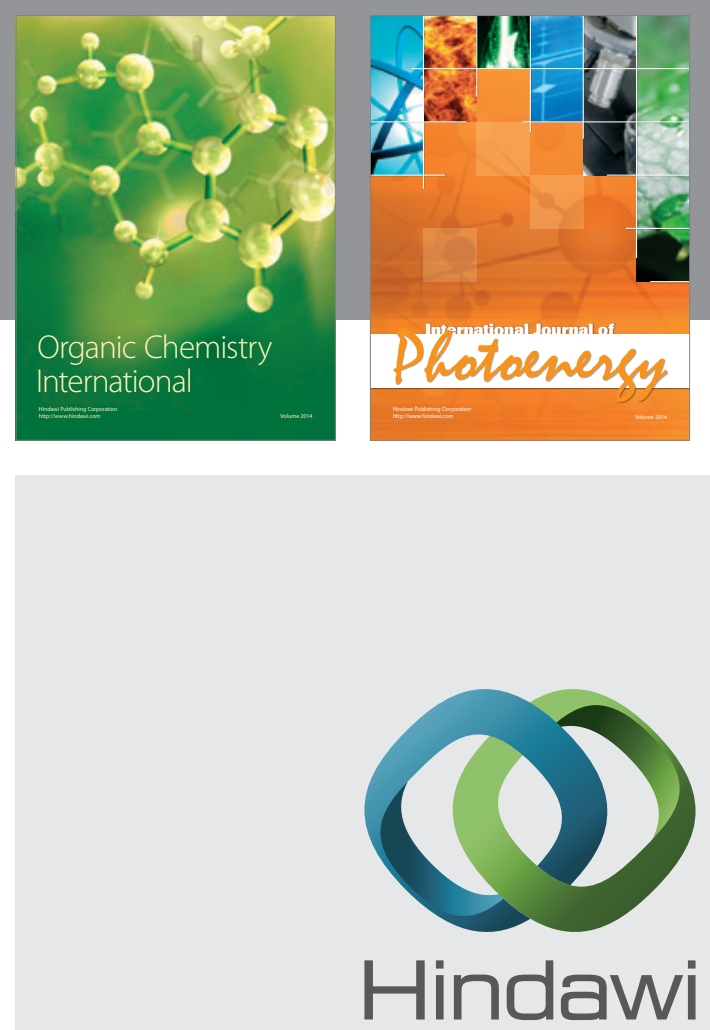

Submit your manuscripts at

http://www.hindawi.com
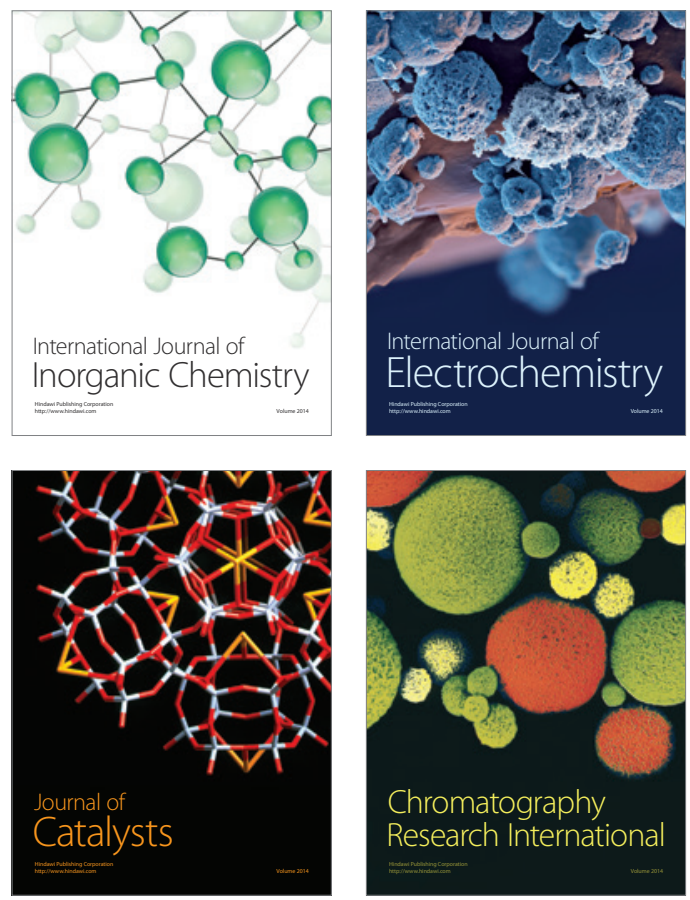
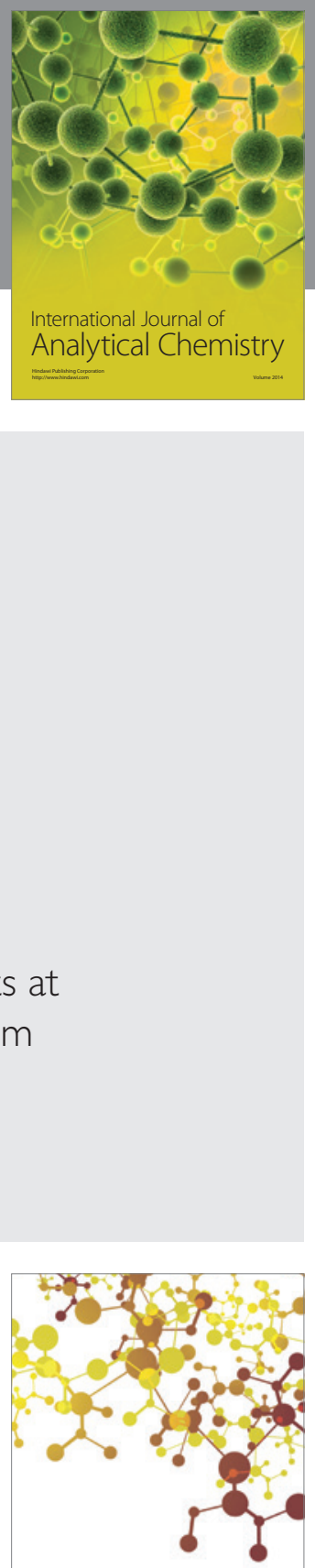

Journal of

Applied Chemistry
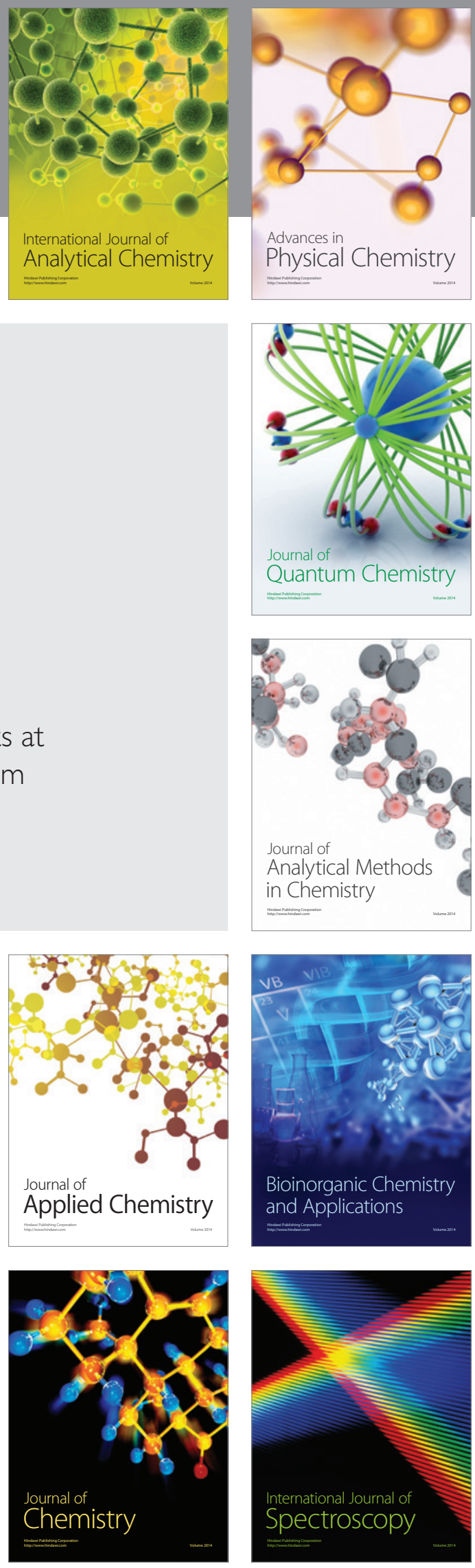